\title{
Seasonal changes in specific growth rates, production and biomass of a bacterial community in the water column above a Mediterranean seagrass system
}

\author{
Branko Velimirov, Martha Walenta-Simon* \\ Institut für Allgemeine Biologie, Abt. Mikrobiologie, Universität Wien, Schwarzspanierstraße 17, A-1090 Wien, Austria
}

ABSTRACT: Bacterial abundance, biomass and production rates were determined at 3 depths $(5,10 \&$ $15 \mathrm{~m}$ ) in the water column above a Mediterranean seagrass bed in the Gulf of Calvi (west coast of Corsica, France) from 1988 to 1990. We used dialysis bags for in situ incubation of $2 \mu \mathrm{m}$ prefiltered seawater sampled from the respective depths to determine bacterial growth parameters and conducted light- and dark-bottle incubations to estimate planktonic primary production by $\mathrm{O}_{2}$ measurements Bacterial density and biomass was subject to marked seasonal changes. Bacterial density varied clearly over the seasons and between the 3 depths, with maximum values being recorded in Aug and Oct 1988 at the 10 and $15 \mathrm{~m}$ depths. Differences in bacterial biomass and density patterns were mainly attributed to changes of abundance and biovolume of rod-shaped bacteria. Highest carbon values were recorded during the summer months in 1989 and 1990 at the 3 depths and ranged from 32 to $65 \mu \mathrm{g} \mathrm{Cl}^{-1}$ Bacterial growth rates were closely correlated to temperature, with highest specific growth rates $(0.075$ to $0.125 \mathrm{~h}^{-1}$ ) found in summer, when chlorophyll a concentrations were at a minimum during this season. During Jan and Feb 1989 and 1990, when chl a concentrations were at a maximum, bacterial growth rates were below $0.001 \mathrm{~h}^{-1}$ Doubling times $(g)$ ranged from 5.2 to $23 \mathrm{~h}$ in summer, being lowest at the $5 \mathrm{~m}$ depth. Highest $g$ values were recorded in Jan 1989 at $10 \mathrm{~m}$ (259 h). During this period we observed an increase bacterial numbers within the dialysis bags, but a decrease in biovolume of the 4 morphotypes. We hypothesize that the observed growth strategy is necessary for bacteria to resist starvation and to obtain a competitive advantage for nutrient scavanging under oligotrophic conditions. In Jan, bacterial production corresponded to $7.6 \%$ of gross primary production. In summer, bacterial production ranged from 18.5 to $48.4 \%$ of gross primary production. Carbon requirements of the bacterial population in the water column were discussed in view of various carbon conversion efficiencies. The range of our bacterial production values is compared with values from other systems and seen in the context of the methodological approaches.

\section{INTRODUCTION}

It is established knowledge that in aquatic systems dominated by vascular plants, most of the primary production is not utilized directly by macroconsumers (Thayer et al. 1975, Ott \& Maurer 1977, Zimmermann et al. 1979, Morgan 1980, Phillips \& McRoy 1980, Traer 1980, Ott 1981, Velimirov 1986, Mann 1988). The bulk of plant material undergoes fragmentation and chemical modification (Velimirov et al. 1981, Morgan \& Kitting 1984, Velimirov 1987 ) before entering the food

\footnotetext{
- Present address: Bundesanstalt für Wassergüte, A-1220 Wien, Austria
}

chain, or is transferred to the higher trophic levels by first being changed into bacterial biomass which is subsequently consumed by bacterivores. Since bacteria are involved in both decomposition processes (Newell et al. 1983) and the transfer of energy to meioand macrofauna (Newell et al. 1982), reliable data on biomass and growth rates of bacteria are needed to understand and quantify the carbon cycle in seagrassdominated ecosystems. However, bacterial degradation in such systems is not restricted to seagrassderived particles; the presence of phytoplanktonic particulate organic carbon (Murray \& Wetzel 1987) and exudates in the water column (Chrost 1981, Chrost \& Faust 1983, Münster \& Chrost 1990) represents easily degradable organic matter compared to the structural 
carbohydrates from vascular plants (Benner et al. 1986, Moran \& Hodson 1989) or their epiphytes. Therefore bacterial biomass and growth dynamics in the water column above the seagrass bed may be different from those within the meadow.

Most information on bacterial biomass and production in seagrass systems is available for Zostera capricomi beds (Moriarty \& Pollard 1981, 1982) and a multi-species seagrass community (Moriarty et al. 1990) in Australia. In general, less information is available for temperate seagrass systems and more specifically, for those of the Mediterranean Sea. Density data relating to bacteria on seagrass debris and leaves of Posidonia oceanica (Velimirov et al. 1981, Novak 1984) as well as in the water column above and within a Posidonia bed (Velimirov 1986a, Velimirov 1987) have been published, but only limited data on bacterial growth rates from a site near the Gulf of Naples, Italy (Velimirov 1989) can be found.

In the following study we report on bacterial biomass as well as on growth rates and production obtained at a site in the Gulf of Calvi (west coast of Corsica, France) which is characterized by an extensive seagrass bed We investigated seasonal variations of the bacteria populations in the water column above the seagrass bed and integrated estimations on chlorophyll a concentrations and phytoplanktonic primary production into the study. As an alternative to the methods of Fuhrman \& Azam (1980), Moriarty \& Pollard (1981) and Moriarty et al. (1990) using thymidine incorporation into DNA to estimate bacterial productivity, we chose to follow growth of microbial populations by direct observation using in situ incubations in dialysis bags (Lochte \& Turley 1985, Turley \& Lochte, 1985).

\section{MATERIALS AND METHODS}

The investigation site was located $300 \mathrm{~m}$ off the research station STARESO in the Gulf of Calvi. A dense Posidonia oceanica bed characterizes the shallow benthos of the gulf, extending from 4 to $35 \mathrm{~m}$ depth, and is adjacent to a deeper sand and mud bottom ecosystem. A detailed description of the site is given by Bay (1984). Data on wind, main current directions and speed are available from Djenedi (1985). Highest shoot density is found between depths of 10 and $20 \mathrm{~m}$, with an average of 408 shoots $\mathrm{m}^{-2}$ (Bay 1984). All measurements, water sampling and in situ incubations took place at 3 depths $(5,10 \& 15 \mathrm{~m})$ at a permanent station marked by a surface buoy. Depth at this station was $20 \mathrm{~m}$.

Temperature was measured at least twice a month at the 3 depths by SCUBA divers. Multiple water samples for the determination of bacterial density, incubation experiments and chlorophyll a measurements were collected at each of the 3 depths between 1988 and 1990 using 1.4 I IRO bottles. All containers were acidwashed and rinsed with distilled water prior to use. Glassware used for storage of pooled water samples was autoclaved after being cleaned as described above. Two $20 \mathrm{ml}$ aliquots of each pooled sample per depth were preserved with $800 \mu \mathrm{l}$ of $35 \%$ formaldehyde for enumeration and sizing of bacterial cells.

To determine bacterial secondary production, each pooled water sample was taken to the laboratory and gravity-filtered through $2 \mu \mathrm{m}$ pore size Nuclepore polycarbonate filters $(45 \mathrm{~mm}$ diameter) to eliminate most bacterial predators. Each filtered water sample was split into two $1.2 \mathrm{l}$ subsamples and poured into separate pretreated dialysis bags (Union Carbide, $65 \mathrm{~mm}$ inflated diameter, molecular weight cutoff 12000 to 14000 D), modifying the method of Turley \& Lochte (1985). Pretreatment consisted of washing the strips of seamless regenerated cellulose tubing in boiling water for $2 \mathrm{~h}$, rinsing in running tap water overnight, followed by washing for $1 \mathrm{~h}$ in boiling water and further rinsing in distilled water. Each end was sealed by 2 knots, $3 \mathrm{~cm}$ apart. The filtration and filling procedure took approximately 45 min per depth. During transport the bags were kept in a light-tight cooling box. One end was then connected with a polypropylene rope to a bottom weight, while the other end was connected to a small subsurface buoy which kept the bag in an upright position without exerting tension stress on it. SCUBAdivers positioned each pair of dialysis bags at 5,10 and $15 \mathrm{~m}$, respectively, by adjusting the length of the bottom rope. The lowest bag (at the 15 m depth) was lacated approximately $5 \mathrm{~m}$ above the seagrass meadow. Each pair of bags, situated $1 \mathrm{~m}$ apart, was incubated for $24 \mathrm{~h}$.

All bags were collected 24 to $26 \mathrm{~h}$ after immersion (at 45 min intervals) by SCUBA divers and brought to the laboratory within $5 \mathrm{~min}$. Three $20 \mathrm{ml}$ aliquots were taken from each bag to conduct replicate bacterial counts. The acridine orange epifluorescence direct counting technique (Hobbie et al. 1977) was applied to estimate total bacterial number, using a Leitz Diaplan microscope fitted with a Leitz Orthomat E Photosystem (excitation wavelength 450 to $490 \mathrm{~nm}$, cutoff filter $515 \mathrm{~nm}$ ).

Bacteria were sized by eyepiece micrometer, classifying bacteria into cocci, rods, curved rods and spirillae. We counted all cells in a minimum of 30 eyefields per sample and measured between 100 and 180 cells per subsample. Cells were operationally defined as rods if their length and width differed by more than $0.1 \mu \mathrm{m}$. Volume estimations were based on the assumption that all bacteria are spheres or rods (i. e. cylinders with 2 hemispherical caps). The difficulties of obtaining 
reliable size estimates during direct observation in the epifluorescence microscope are demonstrated by Krambeck \& Krambeck (1984), Bratback (1985), Lee \& Fuhrman (1987) and Krambeck et al. (1990). Fluorescent latex beads with diameters of $0.11,0.22,0.6$ and $0.88 \mu \mathrm{m}$ (Polyscience Lim.) were used for calibration of the sizing procedure. Our estimates by eye were controlled using both an automatic image analyzer (LeitzASBA III) and a semi-automatic image analyzer (LeitzASM $68 \mathrm{~K}$ ) on magnifications of epifluorescence photomicrographs (Lee \& Fuhrman 1987). We overestimated the diameter of spheres with 0.11 and $0.22 \mu \mathrm{m}$ diameters by $16 \%, 0.6 \mu \mathrm{m}$ diameter by $11 \%$ and $0.88 \mu \mathrm{m}$ diameter by $6 \%$.

The frequency of dividing cells (FDC) was determined by the method of Hagström et al. (1979), and cellular carbon was calculated from the estimated total bacterial volume, using the conversion factor $380 \mathrm{fg} C$ $\mu \mathrm{m}^{-3}$ cell volume after Lee \& Fuhrman (1987). Bacterial growth rate was calculated by the equation for exponential growth: $\mu=\left(\ln N_{2}-\ln N_{1}\right) /\left(t_{2}-t_{1}\right)$ where $N_{1}$ and $N_{2}=$ bacterial abundance at the beginning and the end of an incubation interval; $t_{1}$ and $t_{2}=$ beginning and ending incubation times. The doubling time $g$ was calculated by: $g=\ln 2 / \mu$. Estimation of bacterial production was obtained by: (total bacterial carbon at $t_{2}-$ total bacterial carbon at $\left.t_{1}\right) /\left(t_{2}-t_{1}\right)$.

For chlorophyll measurements we filtered a minimum of 5 to 71 water onto one or several Whatmann GF/F filters using low vacuum $(<0.2 \mathrm{~atm})$. The filters were stored at $-18{ }^{\circ} \mathrm{C}$ in the dark until extraction in $90 \%$ acetone and spectrophotometric determination according to Parsons et al. (1985). Estimates of primary production in the water column were obtained by monitoring the evolution of dissolved oxygen in capacity calibrated light and dark Winkler flasks according to the modified classical Winkler procedures (Parsons et al. 1985). Duplicate light and dark bottles were incubated for $4 \mathrm{~h}$, usually between 10:00 and 14:00 h, at 1, 5,10 and $15 \mathrm{~m}$ depth and always using the same set of bottles for the same depth. Although the incubations were started in August 1988 we only used data from experiments from July 1989 on, which were run at the same time or close to the $24 \mathrm{~h}$ incubation experiments of dialysis bags to determine bacterial growth rates. Temperature readings were performed at the beginning and the end of both types of incubation experiments. To convert $\mathrm{O}_{2}$ values into carbon equivalents, a photosynthetic quotient of 1.36 (Williams \& Robertson 1991) and a respiratory quotient of 1.0 (Holligan et al. 1984, Bender et al. 1987) were used. We used a Metrohm titration sytem (Oudet et al. 1988) consisting of a digital Titroprocessor 686 and a Multidosimat (Dosimat 665) with automatic burette and digital display combined with platinum electrode. Each titration was preceded by a control of the system, using water which was supersaturated with oxygen and water boiled for $40 \mathrm{~min}$ and subsequently flushed with nitrogen.

\section{RESULTS}

The bacterial density pattern from July 1988 to 1990 at $5 \mathrm{~m}$ (Fig. 1) varied substantially from density patterns at the 10 and $15 \mathrm{~m}$ deeper depths. This difference was due to high densities at the $10 \mathrm{~m}$ depth in Aug 1988 $\left(11.5 \times 10^{5}\right.$ cells $\left.\mathrm{ml}^{-1}\right)$ and at the $15 \mathrm{~m}$ depth in Oct 1988 and Jul 1990 with $26 \times 10^{5}$ and $11.23 \times 10^{5}$ cells ml $\mathrm{m}^{-1}$ respectively. In contrast, the $5 \mathrm{~m}$ depth showed a density peak in Jun and Jul 1989 (9.60 and $10.89 \times 10^{5}$ cells $\left.\mathrm{ml}^{-1}\right)$ as well as in Apr $1990\left(8.36 \times 10^{5}\right.$ cells ml $\left.^{-1}\right)$. Although a smaller peak was also noticed from Jan to Jul 1989 for the 10 and $15 \mathrm{~m}$ depths, no such clear peak could be detected at $5 \mathrm{~m}$.
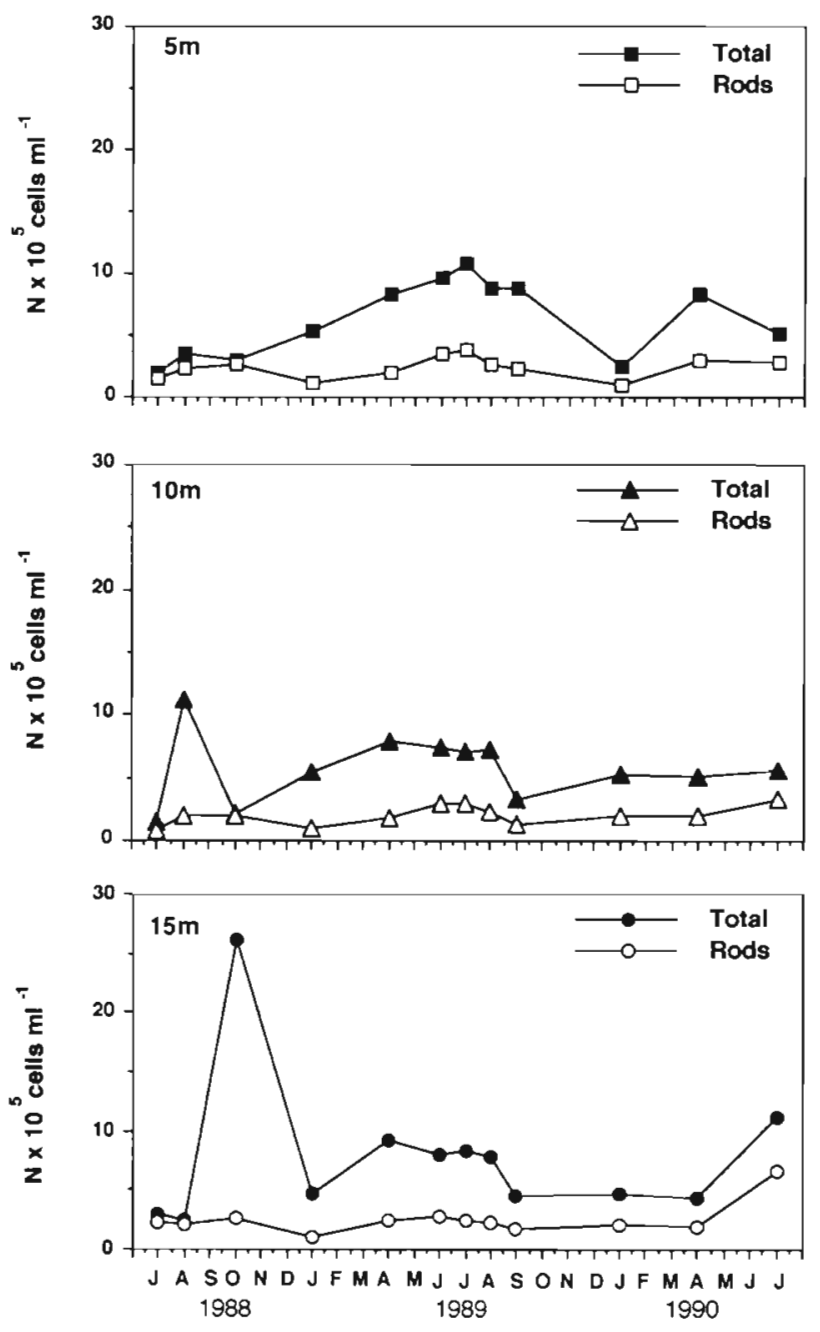

Fig. 1. Variations in total bacterial number and rod-shaped bacteria at 5, 10 and $15 \mathrm{~m}$ depths from 1988 to 1990 
Total bacterial abundance and the number of rodshaped bacteria showed similar variation patterns over the 2 years with the exception of Aug 1988 at $10 \mathrm{~m}$ and Oct 1988 at $15 \mathrm{~m}$. However, for most of the samples from 1989 and 1990, cocci and curved rods were the dominant bacterial morphotype. At the $5 \mathrm{~m}$ depth, the numerical importance of rods was only noticed in samples from 1988 and for Jan 1990. The density peak at $10 \mathrm{~m}$ in Aug 1988 was due to the dominance of cocci, amounting to $89.2 \%$ of the total cell number. Again, high number of rods were only noticed in Jul and Oct; during the remainder of the sampling period, their contribution was below $40 \%$ of total cell number. The peak in Oct 1988 at $15 \mathrm{~m}$ was also due to a dominance of cocci $(82.4 \%)$, and with the exception of Jul and Aug 1988 , the contribution of rods to the total cell number was comparable to that at $10 \mathrm{~m}$.

Bacterial biomass estimates (Fig. 2) showed that variations of bacterial carbon over the investigated period
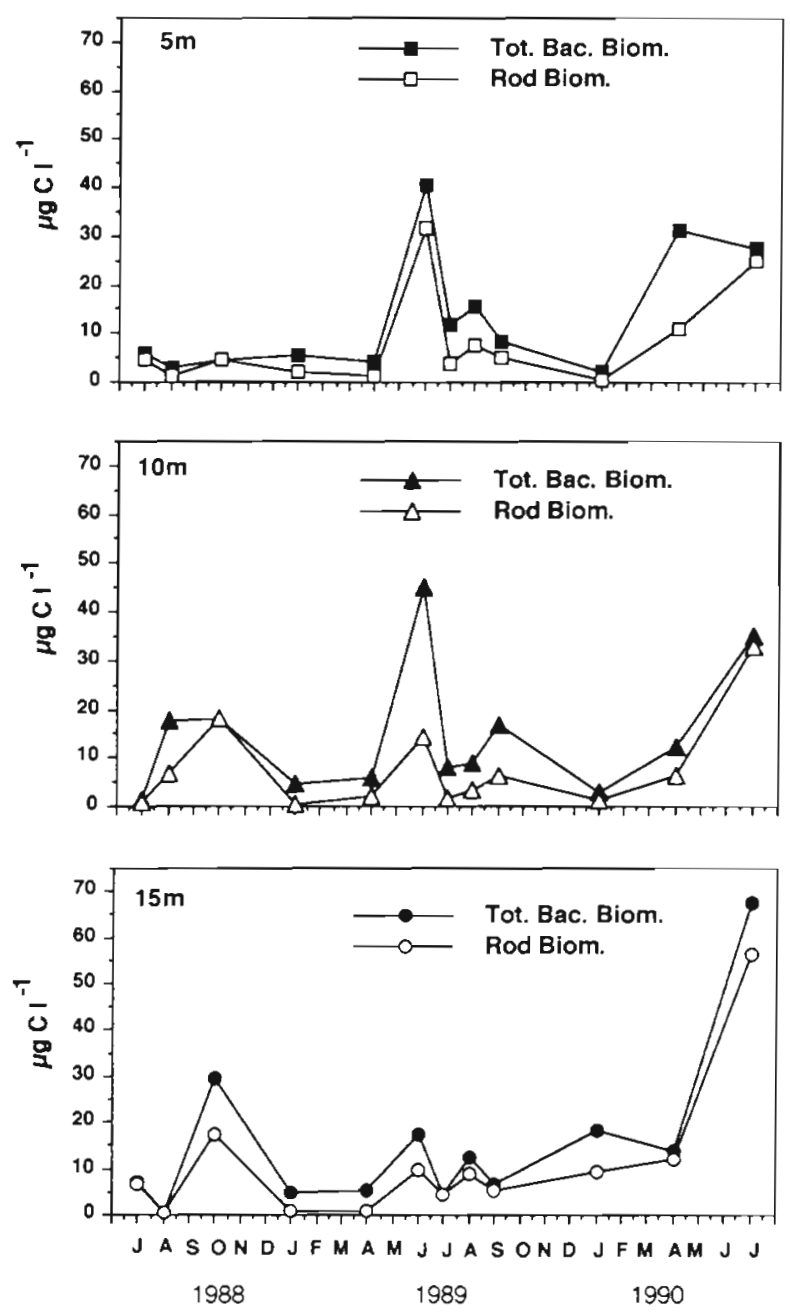

Fig. 2. Changes in bacterial biomass at 5,10 and $15 \mathrm{~m}$ depths from 1988 to 1990 were similar for the $5 \mathrm{~m}$ and $10 \mathrm{~m}$ depths while the pattern at the $15 \mathrm{~m}$ depth showed little similarity. Variations of rod biomass closely followed the variation pattern of the total bacterial biomass; in contrast to their relatively low numerical contribution to the total number (Fig. 1), the biomass contribution was generally above $50 \%$ of the total bacterial biomass. Exceptions were observed in Jul 1989 and Apr 1990 at 5 m, in Jan, Jun and Sept 1989 at $10 \mathrm{~m}$ as well as in Jun and Apr 1989 at $15 \mathrm{~m}$. Maximum biomass values were seen in summer 1989 and 1990 at $5 \mathrm{~m}$ and ranged from 32 to $43 \mu \mathrm{C} \mathrm{C}^{-1}$. At the $10 \mathrm{~m}$ depth 3 summer peaks were seen in the seasonal distribution pattern. The lowest peak value was found for August/October 1988, amounting to $19 \mu \mathrm{g} \mathrm{C}{ }^{-1}$. Although the Aug/Oct peak in 1988 could also be found at $15 \mathrm{~m}$, high carbon values for summer 1989 are missing and bacterial carbon only amounts to $18 \mu \mathrm{g} \mathrm{C} \mathrm{l}^{-1}$. In summer 1990 , however, the highest biomass value of all depths $65 \mu \mathrm{g} \mathrm{C} \mathrm{l}{ }^{1}$, was recorded.

When comparing the curve of specific bacterial growth rates obtained from dialysis bag incubations for the 3 depths with the corresponding temperature curves (Fig. 3), it becomes evident that high growth rates occurred at high water temperatures, while chl a concentrations were at a minimum. During Jan and Feb 1989 and 1990, when maximum chl a concentrations were recorded for all stations, bacterial growth rates were at a minimum.

Table 1 presents our estimates of generation times FDC and bacterial secondary production of the $2 \mu \mathrm{m}$ filtered bacterial population from dialysis bag experiments. Generation times for the summer months (Jun to Sep) ranged from 5.2 to $53 \mathrm{~h}$. Usually the doubling time was lowest at the shallow depth $(5 \mathrm{~m})$ with the exception of Jun 1989 where we calculated a generation time of $2.2 \mathrm{~d}$. FDC values tended to increase with increasing bacterial production rates over the summer months. However, the statistical significance of this trend could only be confirmed at $5 \mathrm{~m}(\mathrm{r}=0.79, \mathrm{p}<0.005)$ by a regression analysis. Bacterial production rates in summer reached $9.8 \mu \mathrm{g} \mathrm{C} \mathrm{l}^{-1} \mathrm{~h}^{-1}$ with a mean value of 3.07 $(S D=2.28)$ and the lowest value being 0.41 at $10 \mathrm{~m}$ in Jul 1988. In Jan and Apr (both characterized by low bacterial production), the highest value was $1.67 \mu \mathrm{g} \mathrm{C}$ $\mathrm{l}^{-1} \mathrm{~h}^{-1}$, average production being as low as $0.72(\mathrm{SD}=$ 0.52 ). In Jan 1989, despite an increase in cell number over $24 \mathrm{~h}, \mathrm{a}$ decrease in bacterial carbon production due to changes of average cell volumes was noticed (see 'Discussion'). Our estimates of bacterial biomass ranged from 1.1 to $32.6 \mu \mathrm{g} \mathrm{Cl}^{-1}$ and represent the $2 \mu \mathrm{m}$ filtered fraction of the population at the beginning of the experiments, providing a basis of comparison with the bacterial biomass from untreated samples shown in Fig. 2. It should be mentioned that in 1989 and 1990, we 

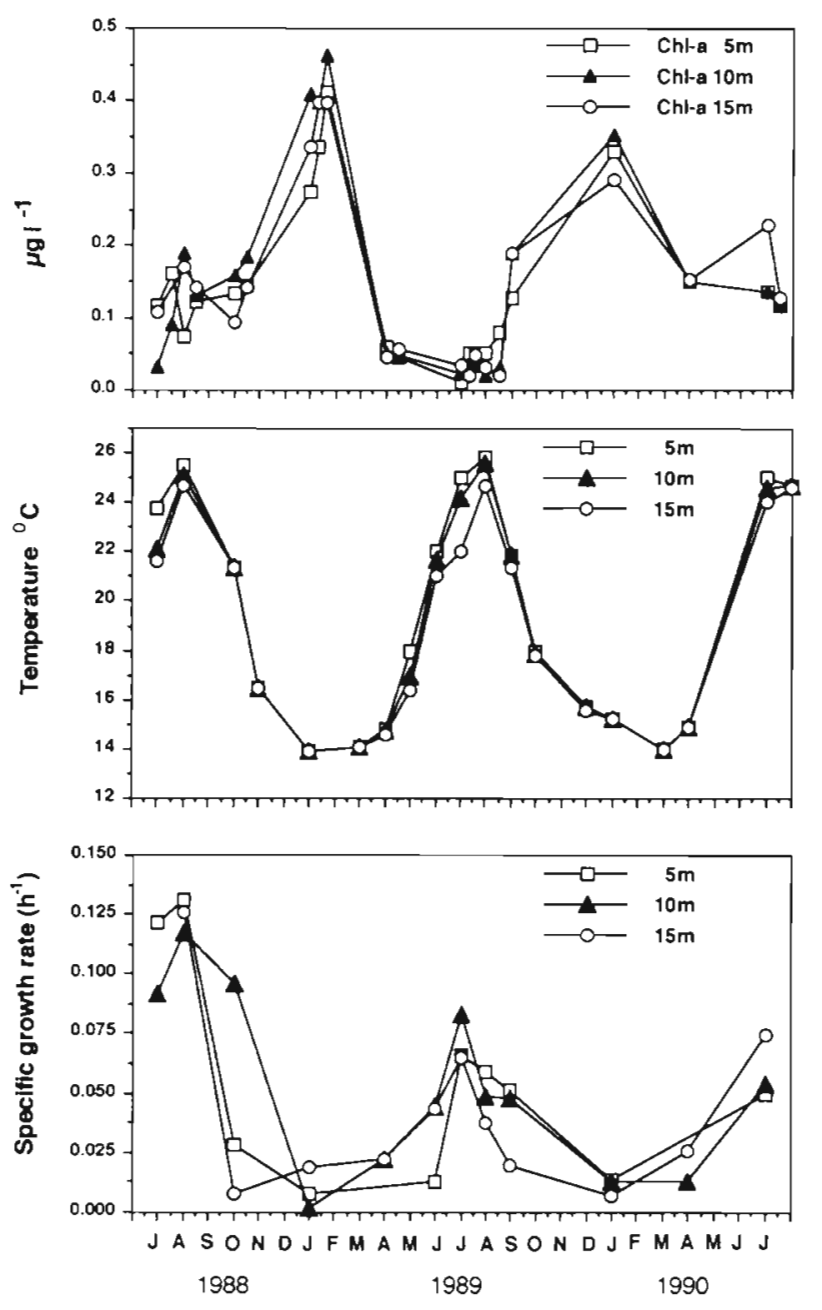

Fig. 3. Variations in chlorophyll a, temperature and specific growth rate $\left(\mathrm{h}^{-1}\right)$ of water column bacteria at 3 depths from 1988 to 1990

had time intervals of over $24 \mathrm{~h}$ between prefiltration of water for dialysis bag experiments and sampling for determination of seasonal bacteria biomass determination. Despite these time intervals, little difference was observed between bacterial biomass from filtered and untreated samples. A significant difference between filtered and unfiltered bacterial biomass variation over the seasons could only be detected for the $15 \mathrm{~m}$ depth ( $F=6.67, p<0.01)$, where higher values were noted for unfiltered samples in Jun 1989, Jan 1990 and Jul 1990. Although relatively high biomass values were also observed in Jan and Jun 1989 for the untreated samples at the other depths, no significant differences in seasonal biomass variations were detected for the $5 \mathrm{~m}$ depth $(F=2.00, p>0.01)$, or the $10 \mathrm{~m}$ depth $(F=2.49$, $\mathrm{p}>0.01)$.

We also compared variations of the average cell volume over the seasons at all depths for prefiltered and unfiltered samples (Fig. 4). No significant differ-
Table 1. Generation time $(g)$, frequency of dividing cells (FDC), standing stocks (biomass), and production of bacterial populations in $2 \mu \mathrm{m}$ filtered water from 3 depths in the water column above a seagrass bed in Calvi (Corsica) from July 1988 to July 1990. Values are the mean of 2 experiments per month. $\mathrm{NP}=$ negative production after $24 \mathrm{~h}$ of incubation; $\mathrm{nd}=$ not determined

\begin{tabular}{|c|c|c|c|c|}
\hline $\begin{array}{l}\text { Month/ } \\
\text { depth }\end{array}$ & $\underset{(h)}{g}$ & $\begin{array}{c}\text { FDC } \\
(\%)\end{array}$ & $\begin{array}{c}\text { Biomass } \\
\left(\mu \mathrm{g} \mathrm{C} 1^{-1}\right)\end{array}$ & $\begin{array}{l}\text { Production } \\
\left(\mu g C^{-1} h^{-1}\right)\end{array}$ \\
\hline \multicolumn{5}{|c|}{ Jul 1988} \\
\hline $5 \mathrm{~m}$ & 5.69 & 2.24 & 5.93 & 3.07 \\
\hline $10 \mathrm{~m}$ & 8.87 & 4.94 & 1.10 & 0.41 \\
\hline $15 \mathrm{~m}$ & nd & nd & 7.13 & nd \\
\hline \multicolumn{5}{|c|}{ Aug 1988} \\
\hline $5 \mathrm{~m}$ & 5.28 & 3.16 & 3.80 & 2.24 \\
\hline $10 \mathrm{~m}$ & 5.95 & 2.31 & 3.20 & 1.57 \\
\hline $15 \mathrm{~m}$ & 5.49 & 2.64 & 6.28 & 1.34 \\
\hline \multicolumn{5}{|c|}{ Oct 1988} \\
\hline $5 \mathrm{~m}$ & 24.70 & 2.50 & 4.78 & 4.03 \\
\hline $10 \mathrm{~m}$ & 7.18 & 1.23 & 18.10 & 2.96 \\
\hline $15 \mathrm{~m}$ & 74.60 & 1.58 & 29.40 & 1.30 \\
\hline \multicolumn{5}{|c|}{ Jan 1989} \\
\hline $5 \mathrm{~m}$ & 83.73 & 3.40 & 6.93 & NP \\
\hline $10 \mathrm{~m}$ & 259.06 & 1.86 & 32.62 & NP \\
\hline $15 \mathrm{~mm}$ & 36.08 & 4.80 & 2.02 & 0.12 \\
\hline \multicolumn{5}{|c|}{ Apr 1989} \\
\hline $5 \mathrm{~m}$ & NP & 3.21 & 4.05 & NP \\
\hline $10 \mathrm{~m}$ & 30.76 & 6.08 & 5.76 & 0.17 \\
\hline $15 \mathrm{~m}$ & 31.46 & 5.40 & 5.34 & 0.61 \\
\hline \multicolumn{5}{|c|}{ Jun 1989} \\
\hline $5 \mathrm{~m}$ & 53.27 & 10.15 & 7.86 & 2.22 \\
\hline $10 \mathrm{~m}$ & 15.41 & 15.35 & 5.92 & 2.79 \\
\hline $15 \mathrm{~m}$ & 14.84 & 23.74 & 6.31 & 1.29 \\
\hline \multicolumn{5}{|l|}{ Jul 1989} \\
\hline $5 \mathrm{~m}$ & 10.54 & 25.81 & 12.61 & 9.84 \\
\hline $10 \mathrm{~m}$ & 8.38 & 16.37 & 9.44 & 3.75 \\
\hline $15 \mathrm{~m}$ & 10.72 & 21.66 & 8.39 & 3.38 \\
\hline \multicolumn{5}{|c|}{ Aug 1989} \\
\hline $5 \mathrm{~m}$ & 11.63 & 13.11 & 31.42 & 4.91 \\
\hline $10 \mathrm{~m}$ & 14.02 & 17.08 & 8.33 & 3.68 \\
\hline $15 \mathrm{~m}$ & 18.33 & 16.13 & 8.00 & 2.49 \\
\hline \multicolumn{5}{|c|}{ Sep 1989} \\
\hline $5 \mathrm{~m}$ & 13.56 & 13.59 & 6.19 & 1.61 \\
\hline $10 \mathrm{~m}$ & 14.98 & 29.00 & 6.42 & 2.53 \\
\hline $15 \mathrm{~m}$ & 23.33 & 17.16 & 9.61 & 0.81 \\
\hline \multicolumn{5}{|c|}{ Jan 1990} \\
\hline $5 \mathrm{~m}$ & 49.81 & 3.62 & 4.32 & 0.16 \\
\hline $10 \mathrm{~m}$ & 63.18 & 11.04 & 5.10 & 0.99 \\
\hline $15 \mathrm{~m}$ & 58.92 & 6.07 & 6.61 & 0.28 \\
\hline \multicolumn{5}{|c|}{ Apr 1990} \\
\hline $5 \mathrm{~m}$ & 167.69 & 0.49 & 25.96 & 0.99 \\
\hline $10 \mathrm{~m}$ & 37.21 & 5.10 & 9.74 & 0.91 \\
\hline $15 \mathrm{~m}$ & 26.56 & 4.07 & 13.80 & 1.67 \\
\hline \multicolumn{5}{|l|}{ Jul 1990} \\
\hline $5 \mathrm{~m}$ & 14.04 & 14.46 & 12.09 & 3.95 \\
\hline $10 \mathrm{~m}$ & 12.90 & 12.55 & 12.45 & 4.86 \\
\hline $15 \mathrm{~m}$ & 9.51 & 19.16 & 4.93 & 3.34 \\
\hline
\end{tabular}

ence in the variations of the mean cell volume could be detected at $5 \mathrm{~m}(\mathrm{~F}=1.12, \mathrm{p}>0.01), 10 \mathrm{~m}(\mathrm{~F}=0.90$, $\mathrm{p}>0.01)$ or $15 \mathrm{~m}(\mathrm{~F}=2.22, \mathrm{p}>0.01)$. 
Measurements of $\mathrm{O}_{2}$ production and consumption for the 3 depths in Fig. 5 revealed a similarity in production and respiration values over the 2 years for the 5 and $10 \mathrm{~m}$ depths. The average summer values for 1989 at the 5 and $10 \mathrm{~m}$ depths $\left[33.2(\mathrm{SD}=4.27) \text { and } 25.86 \mu \mathrm{g} \mathrm{O}_{2}\right]^{-1}$ $\mathrm{h}^{-1}(\mathrm{SD}=6.89)$ respectively] were higher than those found in summer 1990 [21.25 (SD = 8.42) and $18.89 \mu \mathrm{g}$ $\left.\mathrm{O}_{2} l^{-1} \mathrm{~h}^{-1}(\mathrm{SD}=11.46)\right]$. The production values at $15 \mathrm{~m}$ ranged from 15 to $46 \mu \mathrm{O}_{2} \mathrm{l}^{-1} \mathrm{~h}^{-1}$, the highest value being recorded in Apr 1990. The average production value for summer 1989 was $25.71 \mu \mathrm{g} \mathrm{O}_{2} \mathrm{l}^{-1} \mathrm{~h}^{-1}$ (SD = 7.32), comparable to the $10 \mathrm{~m}$ depth, while the mean summer value for 1990 was $11.60 \mu \mathrm{g} \mathrm{O}_{2} 1^{-1} \mathrm{~h}^{-1}(\mathrm{SD}=$ 3.85 ), the lowest summer average of all stations.

To relate bacterial production to primary production in the water column, we expressed hourly production rates of bacteria as percentage of gross primary production from parallel incubation experiments with light
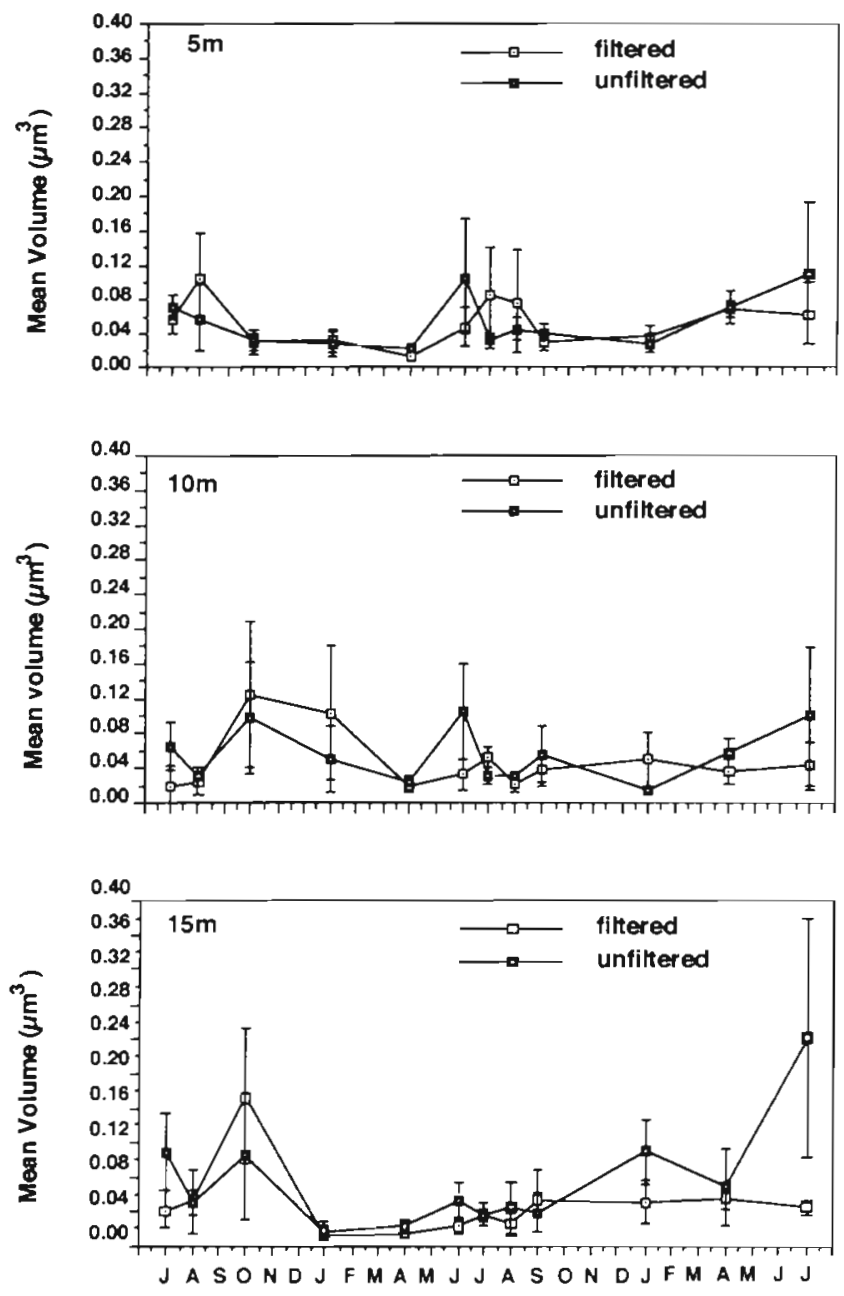

Fig. 4. Mean bacteria cell volume in $2 \mu \mathrm{m}$ filtered and unfiltered water samples from the 5,10 and $15 \mathrm{~m}$ depth (Mean \pm $\mathrm{SD})$ from 1988 to 1990
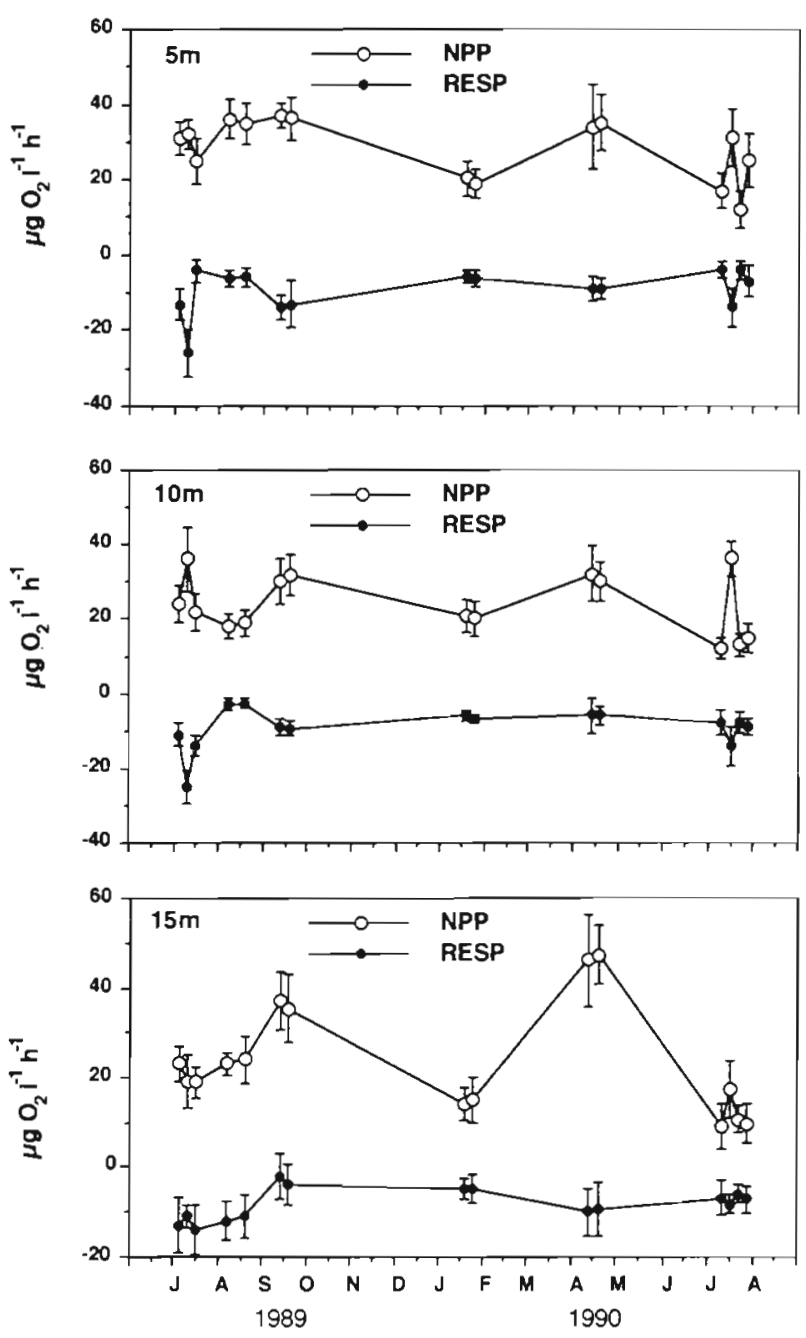

Fig. 5. Oxygen production and consumption in the water column at the $5 \mathrm{~m}, 10 \mathrm{~m}$ and $15 \mathrm{~m}$ depth station (Mean $\pm \mathrm{SD}$ ). NPP: Oxygen evolution in light bottle, RESP: Oxygen evolution in dark bottles

and dark bottles (Table 2). In Jan and Apr bacterial production corresponded at most to $7.6 \%$ of the gross primary production, with the lowest bacterial production representing only $1.3 \%$. A different situation was noticeable in summer; in Jul and Aug 1989 bacterial production ranged from 15.2 to $48.4 \%$ of gross primary production. The highest bacterial production value for Jul 1990 was measured at the $10 \mathrm{~m}$ depth and corresponded to $36 \%$ of the gross primary production.

\section{DISCUSSION}

Comparison of seasonal bacterial growth rates (Fig. 3) with the temperature curve indicates that high growth rates mostly occur above $16{ }^{\circ} \mathrm{C}$. At least on a seasonal basis, it seems that bacterial growth rates are 
Table 2. Gross primary production (GPP) and bacterial secondary production (BP), expressed as percentage of GPP for the investigation periods between. July 1989 and 1990. Data are mean values of all incubation experiments within the month of investigation as follows: GPP: 11,13 and $17 \mathrm{Jul}, 9$ and $20 \mathrm{Aug}$, 25 and 26 Sep 1989; 29 and 30 Jan, 16 and 17 Apr, 14, 17, 21 and 27 Jul 1990. BPP: 7, 8, 15 and 16 Jul, 7, 8, 18 and 19 Aug, 23, 24, 26 and 27 Sep 1989; 29 and 30 Jan, 13, 14, 17 and 18 Apr, 14, 15, 19 and 20 Jul 1990

\begin{tabular}{|lrcc|}
\hline Month & $\begin{array}{c}\text { Depth } \\
(\mathrm{m})\end{array}$ & $\begin{array}{c}\text { Gross primary } \\
\text { production }(\mathrm{GPP}) \\
\left(\mu \mathrm{C} \mathrm{I}^{-1} \mathrm{~h}^{-1}\right)\end{array}$ & $\begin{array}{c}\text { Bacterial } \\
\text { production } \\
\text { (\% of GPP) }\end{array}$ \\
\hline Jul 1989 & $5 \mathrm{~m}$ & 20.33 & 48.40 \\
& $10 \mathrm{~m}$ & 20.18 & 18.53 \\
Aug 1989 & $15 \mathrm{~m}$ & 10.85 & 31.15 \\
& $5 \mathrm{~m}$ & 20.16 & 24.35 \\
Sep 1989 & $10 \mathrm{~m}$ & 10.52 & 34.98 \\
& $15 \mathrm{~m}$ & 16.29 & 15.28 \\
Jan 1990 & $5 \mathrm{~m}$ & 23.77 & 6.77 \\
& $10 \mathrm{~m}$ & 19.27 & 13.12 \\
& $15 \mathrm{~m}$ & 19.58 & 4.13 \\
Apr 1990 & $5 \mathrm{~m}$ & 12.20 & 1.31 \\
& $10 \mathrm{~m}$ & 12.89 & 7.68 \\
& $15 \mathrm{~m}$ & 9.25 & 3.02 \\
Jul 1990 & $5 \mathrm{~m}$ & 20.97 & 4.72 \\
& $10 \mathrm{~m}$ & 18.06 & 5.03 \\
& $15 \mathrm{~m}$ & 27.40 & 6.09 \\
& $5 \mathrm{~m}$ & 13.55 & 29.15 \\
& $10 \mathrm{~m}$ & 13.21 & 36.79 \\
& $15 \mathrm{~m}$ & 8.59 & 38.88 \\
\hline
\end{tabular}

not related to the phytoplankton biomass maxima, which occur when bacterial growth rates are lowest. Our data on chl a concentrations obtained during winter and spring are in agreement with those recorded by Brohee et al. (1989) in the Gulf of Calvi from Mar to Apr 1986. With the exception of 2 peaks of chl a amounting to $1.5 \mu \mathrm{g} \mathrm{l}^{-1}$ (Brohee et al. 1989) and being recorded during a daily sampling program in Mar 1986, their values are in close agreement with our findings, showing a similar concentration decrease in chl a $\left(0.15 \mu \mathrm{g} \mathrm{l}^{-1}\right)$ for April 1986 as we recorded in April 1989. A point deserving attention is that lowest rates of primary production (Table 2) were measured in Jan, when chl a values were at a maximum, while in summer, with the exception of Jul 1990, primary production rates were high. As mentioned by other authors (Larsson \& Hagström 1982, Hagström \& Larsson 1984, Lancelot \& Billen 1984) phytoplanktonic exudate release occurs mainly in summer, thus stimulating bacterial growth but being generally lower in winter when phytoplanktonic biomass may be high but production rates are low. We speculate that the strong seasonal effect on bacterial growth is not mainly due to the effect of changing temperature but rather to seasonal peaks of phytoplankton exudation occurring in summer.

\section{Changes of bacterial cell volumes under low tempera- ture conditions}

A contrasting situation with respect to growth rates and corresponding changes in bacterial carbon production was noted in Jan 1989. Despite an increase in cell number at all 3 depths we calculated a decrease of bacterial carbon production over the $24 \mathrm{~h}$ incubation period. Generation times in Jan were long (from 36 to

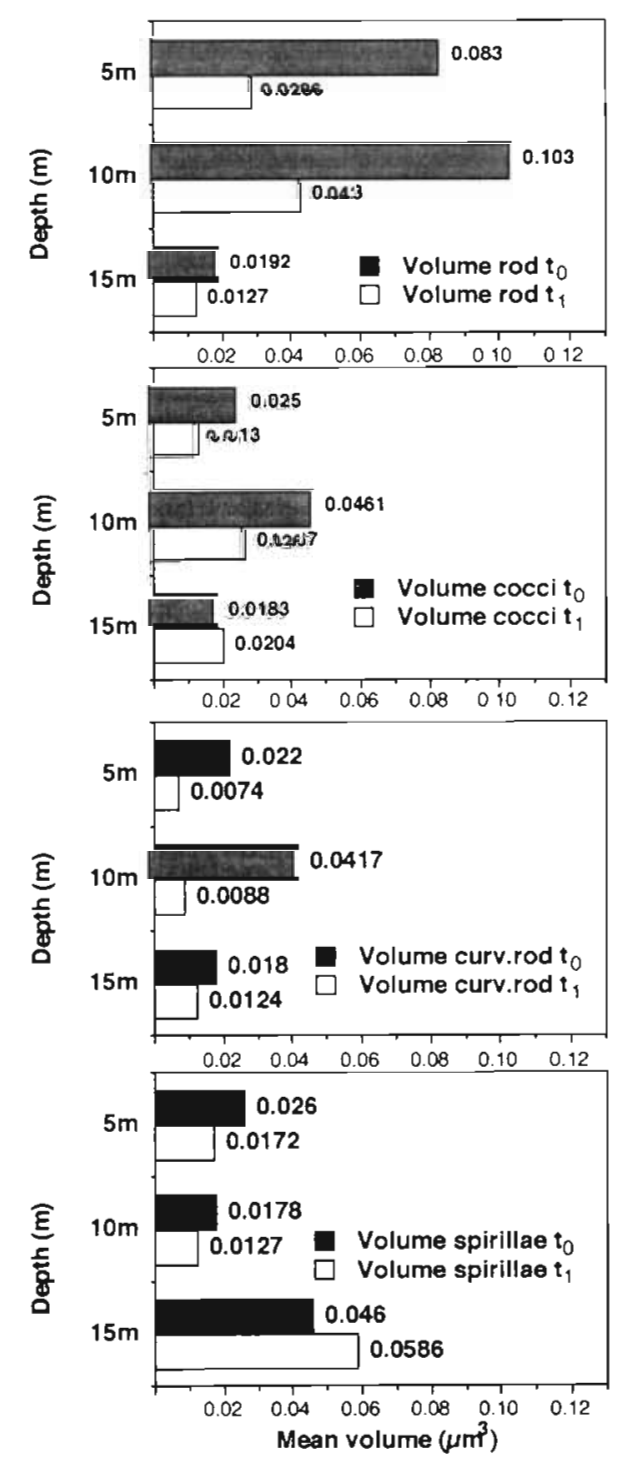

Fig. 6. Comparison of cell volumes for the bacteria morphotypes at beginning and at end of dialysis incubation experiments at 3 depths in January 1989. to: bacterial volume at beginning of incubation experiment; $t_{1}$ : bacterial volume at end of incubation experiment; $t_{1}-t_{0}=24 \mathrm{~h}$ 
$259 \mathrm{~h}$ ), FDC ranged from $1.8 \%$ of $4.8 \%$ but bacterial carbon production was negative. The analysis of bacterial cell volumes showed that the volumes of most morphotypes decreased over the incubation time (Fig. 6). The volume change was most pronounced for rods at the $5 \mathrm{~m}$ and $10 \mathrm{~m}$ depths with a decrease by more than one-half. A significant decrease in mean cell volume of rods was detected at $5 \mathrm{~m}(\mathrm{~F}=17.5, \mathrm{n}=200$, $\mathrm{p}<0.01)$, at $10 \mathrm{~m}(\mathrm{~F}=3.25, \mathrm{n}=180, \mathrm{p}<0.01)$ and at $15 \mathrm{~m}(\mathrm{~F}=6.00, \mathrm{n}=200, \mathrm{p}<0.01)$. A similar situation was observed for curved rods, where mean cell volumes were significantly smaller after the incubation at all depths. For cocci, a significant decrease in mean cell volume was observed for the 5 and $10 \mathrm{~m}$ depths, but could not be confirmed for the $15 \mathrm{~m}$ depth $(\mathrm{F}=0.857$, $\mathrm{n}=190, \mathrm{p}>0.1)$. Spirillae were shown to decrease significantly in volume at $5 \mathrm{~m}(\mathrm{~F}=10, \mathrm{n}=140$, $\mathrm{p}<0.01$ ) but at $10 \mathrm{~m}$ and $15 \mathrm{~m}$ station significant volume differences could not be confirmed. Such observations were never made for summer incubations, and in most experiments from Jun to Oct we recorded increasing mean cell volumes as well as increasing cell numbers. The tendency of decreasing cell volumes during the winter seasons is confirmed by the variation of the average bacterial cell volume over the seasons at the $5 \mathrm{~m}$ depth (Fig. 4) and at least partly supported by the volumes recorded in unfiltered water in Jan and Apr 1989 at the $15 \mathrm{~m}$ depth. This appearance of small cell volumes during winter incubations could indicate that bacteria display different growth strategies over the year. Previous to this study, only the increase of bacterial cell volumes under experimental conditions, where predation pressure is reduced by filtration of the water samples, was recorded on several occasions by various authors for dialysis experiments and seawater cultures (Turley \& Lochte 1985, 1986, Herndl \& Malacic 1987, Velimirov 1989). However, there is no indication that the bacterial volume decrease for the winter incubation experiments is related to higher grazing rates on bacteria compared to the other experiments. All water samples were treated with the same filtration procedure, and heterotrophic flagellates which passed the $2 \mu \mathrm{m}$ pore size filter did not increase in abundance during the experimentation time. In unfiltered samples used for determination of bacterial abundance and biomass we found low densities of ciliates (4 to 10 ciliates $\mathrm{ml}^{-1}$ ) and heterotrophic flagellates ranging from 70 to 100 individuals $\mathrm{ml}^{-1}$. Filtration of these samples removed all ciliates and reduced the flagellates on average to $15 \mathrm{ml}^{-1}$ In most samples taken in Jan, flagellate density after filtration was $<7 \mathrm{ml}^{-1}$ without a noticeable increase in number after the incubation period. This observation was confirmed by our seawater culture experiments where an increase of flagellates could only be recorded after $52 \mathrm{~h}$ (Velimirov
\& Walenta-Simon unpubl.). The decrease of cell volume was not restricted to the winter period and also took place in Apr 1989 at the 10 and $15 \mathrm{~m}$ depths. We hypothezised that an increase in bacterial number together with a decrease in size may be an appropriate growth strategy under unfavorable environmental conditions. Despite an overall loss of carbon during the process of cell division, the favorable surface-tovolume ratio resulting from the decrease in size may be of advantage to harvest dissolved organic and inorganic nutrients under oligotrophic conditions. Furthermore, environmental events leading to an increase of exudates resulting from occasional bursts of phytoplankton production in winter due to input of inorganic nutrients by upwelled water (Brohee et al. 1989) or resuspension of sediments and pore water nutrients due to winter storms can be used efficiently by a population dominated by small bacteria. The phenomenon of non-growth (Kjelleberg et al. 1983, 1987. Güde 1990) or decreasing cell volume by marine bacteria was repeatedly observed in laboratory experiments as a response to starvation (Novitsky \& Morita 1978, Amy \& Morita, 1983) and could be triggered by reducing nutrient levels in culture media of various Vibrio species (Hood et al. 1986). Also, fast recovery from nutrient starvation was observed for marine psychrophilic Vibrio species, and a doubling of cell volume was recorded $8 \mathrm{~h}$ after nutrient addition (Amy et al. 1983). These experiments support our speculation based on observations from in situ experiments with dialysis bags that cell volume reduction of bacteria during periods of low temperature and low primary production in the water column may be a strategy enabling bacteria to resist starvation and increase their potential for a competitive advantage in nutrient scavenging.

\section{Implications of incubation experiments with dialysis bags}

Before attempting to use data from dialysis bag experiments for a more generalized view of the bacterial production in the water column, it was necessary to consider a number of methodological implications. We were able to record direct changes in cell number and biovolume by using dialysis bags because bags possess a combination of qualities necessary for bacterial incubation experiments in situ such as sterilizability, strength of the membranes and good diffusivity (for details see Turley \& Lochte 1985). Possible disadvantages include the filtration process before incubation and the enclosure conditions of the bacterial population resulting from membrane characteristics of the bags. 
Despite prefiltration of our samples we did not expect an important change in the bacterial population (above) and assumed that the enclosed bacteria represented the active fraction of free bacteria in the water column. This is in agreement with earlier studies (Ferguson \& Rublee 1976, Watson et al 1977, Sieburth et al. 1978) on size distributions in microbial communities and activity studies (Hoppe 1983) which detected maximum enzyme activity in the 0.2 to $0.6 \mu \mathrm{m}$ fraction. However, filtration removes most of the particulate organic matter above $2 \mu \mathrm{m}$ diameter as well as the attached bacteria on these particles. Thus, our estimated bacterial production values are restricted to the free bacteria and bacteria attached to particles below $2 \mu \mathrm{m}$. The contribution of attached bacteria on the larger particle size classes to the total bacterial production of the water column is difficult to assess and may lead to an underestimation of the total production. However, it was found that larger seagrass and epiphyte-derived particles are only suspended during periods of strong water movement, have fast settling rates and were poorly colonized by bacteria (Velimirov 1987). Therefore we assumed that bacteria attached to larger particles do not contribute significantly to the total bacterial production in the water column.

A second disadvantage in using dialysis bags was the possibility of bacterial growth on the membranes, observed by several authors after $3 \mathrm{~d}$ of incubation (Sieburth 1976, 1979, Vargo et al. 1975), leading to a potential inhibition of diffusion by blocking the pores of the membrane. To avoid this situation, all of our incubation experiments were limited to 24 to $26 \mathrm{~h}$. Furthermore, the connection between bacteria enclosed in the dialysis bag and the dissolved organic and inorganic matter of the surrounding water body is not established at the same rate as in the undisturbed water column. Although various authors have observed that growth is not restricted by diffusion or by a build up of toxic substances (Gerhardt \& Gallup 1963, Schultz \& Gerhardt 1969) and that growth in experimental bags is exponential, it should still be taken into consideration that the diffusion rate of low molecular weight DOC is expected to be reduced by 40 to $60 \%$ as compared to the diffusion rate in water alone. Therefore the recorded growth rates from dialysis bags may tend to underestimate the potential bacterial growth, especially in experiments where organic nutrients may be a limiting factor.

\section{Carbon requirements of the bacterial community in the water column}

As mentioned earlier, bacterial carbon production values within a year may be grouped into 2 periods, characterized by temperature regimes below $16^{\circ} \mathrm{C}$ (Nov to Apr) and above $16^{\circ} \mathrm{C}$ (May to Oct). Table 3 allows a comparison of estimated mean biomass and production values for $1 \mathrm{l}$ of seawater, assumed to be representative for each of the 3 depths, and provides a basis for speculations on the magnitude of carbon flow between the main compartments in the water column. It can be seen that the seasonal variations in bacterial productivity for the 2 temperature regimes within the year are more pronounced than that of primary productivity. This may be partly due to high primary production values in April, when temperature reaches late spring and summer values. Assuming a carbon conversion efficiency of $50 \%$, which is close to values obtained from studies using isotope-labeled low molecular weight substrates (Iturriaga \& Hoppe 1977. Bell \& Sakshaug 1980, Billen et al. 1980, Iturriaga \& Zsolnay 1981), it is obvious that to allow a bacterial carbon production in summer ranging from 47.7 to

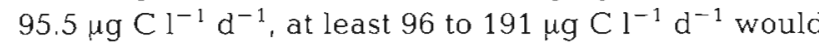
be required. If we base our calculations on a conversion efficiency of $20 \%$, as recommended by researchers using direct methods and substrates as phytoplankton detritus (Newell et al. 1981 Bell \& Kuparinen, Linley \& Newell 1984, Bauernfeind 1985, Bjornsen 1986), some 238 to $477 \mu \mathrm{g} \mathrm{C}^{-1} \mathrm{~d}^{-1}$ would be required. Such a carbon requirement could not be covered by phytoplankton production alone and would imply that a carbon input from the seagrass meadow into the water column takes place. In order to decide on the appropriate magnitude of a carbon conversion efficiency representative for the situation in our dialysis bags, we have to consider the fact that over 24 to $26 \mathrm{~h}$ incubation we measured primary production of water column bacteria, based on degradation and uptake of dissolved organic substances. Therefore it was appropriate to expect organic carbon conversion with an efficiency closer to $50 \%$ than to $20 \%$, assuming that phytoplankton production can support all bacterial secondary production in the water column. A different situation is noted for the colder period of the year. To support the bacterial production between Nov and Apr (Table 3), 40.8 to $62.4 \mu \mathrm{g} \mathrm{C} \mathrm{l}^{-1} \mathrm{~d}^{-1}$ are required when a factor of

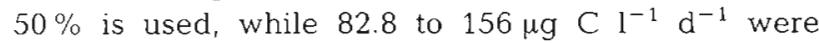
estimated to be required for a $20 \%$ carbon conversion efficiency. All estimated values are well within the range of primary production during this season.

It is obvious that our data, based on growth characteristics of confined bacterial populations, should be applied with caution to field conditions. Nonetheless, we believe that the average production rates for summer and winter reflect the production potential of the water column bacteria above our seagrass bed. Bacterial production rates from the water column above a shallow tropical seagrass bed and a reef flat colonized 
Table 3. Comparison of averaged values for heterotrophic bacteria biomass (HBB), bacterial secondary production (BSP) and primary production for periods of high $\left(>16^{\circ} \mathrm{C}\right)$ and low $\left(<16^{\circ} \mathrm{C}\right)$ temperature regimes over a year at the 3 depths

\begin{tabular}{|c|c|c|c|c|c|c|}
\hline \multirow[t]{2}{*}{ Depth } & \multicolumn{2}{|c|}{$\mathrm{HBB}\left(\mu \mathrm{g} \mathrm{C} \mathrm{I^{-1 } )}\right.$} & \multicolumn{2}{|c|}{$\operatorname{BSP}\left(\mu \mathrm{g} \mathrm{Cl^{-1 }} \mathrm{d}^{-1}\right)$} & \multicolumn{2}{|c|}{$\mathrm{PP} \cdot\left(\mu \mathrm{g} \mathrm{Cl} \mathrm{l}^{-1} \mathrm{~d}^{-1}\right)$} \\
\hline & Mean & Range & Mean & Range & Mean & Range \\
\hline \multicolumn{7}{|c|}{ May to October (Temperature $>16^{\circ} \mathrm{C}$ ) } \\
\hline $5 \mathrm{~m}$ & 14.47 & $3.08-40.54$ & 95.52 & $38.64-236.16$ & 229.48 & $94.76-324.31$ \\
\hline $10 \mathrm{~m}$ & 13.72 & $1.10-45.17$ & 67.69 & $9.84-116.64$ & 192.07 & $113.45-345.02$ \\
\hline $15 \mathrm{~m}$ & 13.55 & $0.59-67.55$ & 47.76 & $19.44-81.12$ & 164.08 & $94.60-222.88$ \\
\hline \multicolumn{7}{|c|}{ November to April (Temperature $<16^{\circ} \mathrm{C}$ ) } \\
\hline $5 \mathrm{~m}$ & 11.29 & $2.12-31.32$ & 31.20 & $23.76-38.64$ & 172.72 & $101.84-244.30$ \\
\hline $10 \mathrm{~m}$ & 10.41 & $2.74-32.62$ & 16.20 & $4.08-23.76$ & 158.91 & $109.95-213.74$ \\
\hline $15 \mathrm{~m}$ & 8.66 & $2.74-18.40$ & 20.40 & $6.72-40.08$ & 197.17 & $76.89-317.58$ \\
\hline
\end{tabular}

by seagrass (Moriarty et al. 1990) ranged from 12 to $72 \mu \mathrm{g} \mathrm{Cl}^{-1} \mathrm{day}^{-1}$, which is in agreement with averaged rates obtained from dialysis bag experiments, with the exception of the higher values at $5 \mathrm{~m}$, monitored during the summer temperature regime. Also, the bacterial production range from a saltmarsh system dominated by Spartina was 36 to $242.4 \mu \mathrm{g} \mathrm{Cl}^{-1} \mathrm{day}^{-1}$ (Newell et al. 1983), similar to the production ranges from our summer experiments. A comparison of our data with bacterial production ranges obtained in other ecosystems shows that high rates were also reported by Vyshkvartsev (1980) who monitored the increase in biovolume, by Newell \& Christian (1981) who used frequency of dividing cells to estimate production rates, and Sieburth et al. (1977) who recorded ATP increase in diffusion cultures. Preliminary results from our seawater culture experiments (unpubl, data) seem to confirm our production estimates for both the summer and winter season.

Acknowledgements. This work was supported by the Fonds zur Förderung der wissenschaftlichen Forschung Projekt Nr. P 6559 B. We thank R. J. Chrost and 3 anonymous referees for comments and constructive criticism on the manuscript, STARESO SA. for providing laboratory facilities, A. Thiry, F. Wernerus and D. Bay for boat and diving assistance and K. Hallmann for help in preparing the manuscript.

\section{LITERATURE CITED}

Amy, P. S., Morita, R. Y. (1983). Starvation-survival patterns of sixteen freshly isolated open-ocean bacteria. Appl. environ. Microbiol 45: 1109-1115

Amy, P. S., Pauling, C., Morita, R. Y (1983). Recovery from nutrient starvation by a marine Vibrio sp. Appl environ. Microbiol 45: 1685-1690

Bauerfeind, S. (1985). Degradation of phytoplankton detritus by bacteria: estimation of bacterial consumption and respiration in an oxygen chamber. Mar. Ecol. Prog. Ser. 10: 257-263
Bay, D. (1984). A field study of the growth dynamics and productivity of Posidonia oceanica (L) DELILE in Calvi Bay, Corsica. Aquat. Bot. 20: 42-64

Bell, R. T., Kuparinen, J. (1984). Assessing phytoplankton and bacterioplankton production during early spring in Lake Erken, Sweden. Appl environ. Microbiol. 48: 1221-1230

Bell, W. H., Sakshaug, E. (1980). Bacterial utilization of algal extracellular products. 2. A kinetic study on natural populations. Limnol. Oceanogr. 25: 1021-1033

Bender, M., Grande, K., Johnson, K., Marra, J., Williams, P. J. leB., Sieburth, J., Pilson, M., Langdon, C., Hitchcock, G., Orchado, J., Hunt, C., Donaghay, P., Heinemann, K. (1987). A comparison of four methods for determining planktonic community production. Limnol. Oceanogr. 32: 1085-1098

Benner, R., Moran, M. A., Hodson, R. E. (1986). Biogeochemical cycling of lignocellulosic carbon in marine and freshwater ecosystems: relative contribution of procaryotes and eucaryotes. Limnol. Oceanogr. 31: 89-100

Billen, G., Joiris, C., Wijnant, J., Gillian, G. (1980). Concentrations and microbiological utilization of small organic molecules in Scheldt Estuary, the Belgian Coastal zone and the English Channel. Estuar. coast. mar. Sci. 11: 279-294

Bjornsen, P. K. (1986). Bacterioplankton growth yield in continuous seawater cultures. Mar. Ecol. Prog. Ser. 30: 191-196

Bratbak, G. (1985). Bacterial biolvolume and biomass estimations. Appl. environ. Microbiol. 49: 1488-1493

Brohee, M. Goffard, A., Frankignoulle, M., Henri V., Mouchet, A. Hecq, J. H. (1989). Variations printanières des communautés planctoniques en baie de Calvi (Corse) en relation avec les contraintes physiques locales. Cah. Biol. Mar. 30: 321-328

Chrost, R. J. (1981). The composition and bacterial utilization of DOC released by phytoplankton. Kieler Meeresforsch., Sonderh. 5: 325-332

Chrost, R. J., Faust, M. (1983). Organic carbon release by phytoplankton: its composition and utilization by bacterioplankton. J. Plankton Res. 5: 477-493

Djenedi, S. (1985). Observations au large de Calvi (Corse) en regime d'été. Bull. Soc. R. Sci. Liege 54: 287-300

Ferguson, R., Rublee, P. (1976). Contribution of bacteria to standing crop of coastal plankton. Limnol. Oceanogr. 21 141-145 
Fuhrman, J., Azam, F. (1980). Bacterioplankton secondary production estimates for coastal waters of British Columbia, Antarctica and California. Appl environ. Microbiol. 39: 1085-1091

Gerhardt, P., Gallup, D. M. (1963). Dialysis flask for concentrated culture of microorganisms. J. Bacteriol 86: 919-929

Güde, H. (1990). Bacterial net production approaching zeroa frequent phenomenon in pelagic environments? Arch. Hydrobiol. Beih. Ergeb. Limnol. 34: 165-169

Hagström, A., Larsson, U., Horstedt, P., Normark, S. (1979). Frequency of dividing cells, a new approach to the determination of bacterial growth rates in aquatic environments. Appl. environ. Microbiol. 37: 805-812

Hagström, A., Larsson, U. (1984). Diel and seasonal variation in growth rates of pelagic bacteria. In: Hobbie, J. E., Williams, P. J. leB. (eds.) Heterotrophic processes in the sea. Plenum Press, New York, p. 249-262

Herndl, G. J., Malacic, V. (1987). Impact of the pycnocline layer on bacterioplancton: dial and spatial variations in microbial parameters in the stratified water column of the Gulf of Trieste. Mar. Ecol. Prog. Ser. 38: 295-303

Hobbie, J. E., Daley, R. J., Jasper, S. (1977). Use of nuclepore filters for counting bacteria by fluorescence microscopy. Appl. environ. Microbiol. 33: 1225-1228

Holligan, P. M., Williams, P. J. leB., Purdie, D., Harris, R. P. (1984). Photosynthesis, respiration and nitrogen supply of plankton populations in stratified, frontal and tidally mixed shelf waters. Mar. Ecol. Prog. Ser. 17: 201-213

Hood, M. A., Guckert, J. B., White, D. C., Deck, F. (1986) Effect of nutrient deprivation on lipid, carbohydrate, DNA, RNA, and protein levels in Vibrio cholerae. Appl. environ. Microbiol. 52: 788-793

Hoppe, H. G. (1983). Significance of exoenzymatic activities in the ecology of brackish water measurements by means of methylumbelliferylsubstrates. Mar. Ecol. Prog. Ser. 11: 299-308

Iturriaga, R., Hoppe, H-G. (1977), Observations of heterotrophic activity on photoassimilated matter. Mar. Biol. 40: 101-108

Iturriaga, R, Zsolny, A. (1981). Transformation of some dissolved organic compounds by a natural heterotrophic population. Mar. Biol. 62: 125-129

Kjelleberg, S., Humprey, B. A., Marshall, K. C. (1983). Initial phase of starvation and activity of bacteria at surfaces. Appl. environ. Microbiol. 46: 978-984

Kjelleberg, S., Hermannsson, M., Marden, P., Jones, G. W (1987). The transient phase between growth and nongrowth of heterotrophic bacteria, with emphasis on the marine environment. Ann. Rev. Microbiol. 41 25-49

Krambeck, C., Krambeck, H. J. (1984). Morphometric analysis of cell-cycle responses in bacterioplankton. Arch. Hydrobiol. 19: 111-118

Krambeck, C., Krambeck, H. J., Schröder, D., Newell, Y. (1990). Sizing bacterioplankton: a juxtaposition of bias due to shrinkage, halos, subjectivity in image interpretation and asymetric distributions. inRetrospect 2: 5-14

Lancelot, C., Billen, G. (1984). Activity of heterotrophic bacteria and its coupling to primary production during the spring phytoplankton bloom in the southern bight of the North Sea. Limnol. Oceanogr 29: 721-730

Larsson, U., Hagström, A. (1982). Fractionated phytopklankton primary production, exudate release, and bacterial production in a Baltic eutrophication gradient. Mar. Biol. 67: $57-70$

Lee, S., Fuhrman, J. A. (1987). Relationships between biovolume and biomass of naturally derived marine bacterioplankton. Appl. environ. Microbiol. 53: 1298-1303
Linley, E. A. S., Newell, R. C. (1984). Estimates of bacterial growth yields based on plant detritus. Bull. mar. Sci. 35: 409-425

Lochte, K., Turley, C. M. (1985). Heterotrophic activity and carbon flow via bacteria in water associated with a tida mixing front. In: Gibbs, P. E. (ed.) Proc. 19th Eur ma: biol Symp. Cambridge Univ. Press, Cambridge, p. 73-85

Mann, K. H. (1988). Production and use of detritus in various freshwater, estuarine and coastal marine ecosystems. Limnol. Oceanogr. 33: 910-930

Morgan, M. D. (1980). Grazing and predation of the grass shrimp Palaemonetes pugio. Limnol. Oceanogr. 25 896-902

Morgan, M. D., Kitting, C. L. (1984). Productivity and utilization of seagrass Halodule wrightii and its attached epiphytes. Limnol. Oceanogr 33: 1066-1076

Moran, M. A., Hodson, R. E. (1989). Formation and bacterial utilization of dissolved organic carbon derived from detrital lignocellulose. Limnol. Oceanogr. 34: 1034-1047

Moriarty, D. J. W., Pollard, P. C. (1981). DNA synthesis as a measure of bacterial productivity in seagrass sediments Mar. Ecol. Prog. Ser. 5: 151-156

Moriarty, D. J. W., Pollard, P. C. (1982). Diel variation of bacterial productivity in seagrass (Zostera capricorni) beds measured by rate of thymidine incorporation into DNA Mar. Biol. 72: 165-173

Moriarty, D. J. W., Roberts, D. G., Pollard, P. C. (1990). Primary and bacterial productivity of tropical seagrass communities in the Gulf of Carpentaria, Australia. Mar Ecol Prog. Ser. 61: 145-157

Münster, U., Chrost, R. J. (1990). Origin, composition and microbial utilization of dissolved organic matter In: Overbeck, J., Chrost, R.J. (eds.) Aquatic microbial ecology: biochemical and molecular approaches. Springer Verlag. New York, p. 8-46

Murray, L., Wetzel, L. R. (1987). Oxygen production and consumption associated with the major autotrophic components in two temperate seagrass communities. Mar. Ecol. Prog. Ser. 38: 231-239

Newell, R. C., Lucas, M. I., Linley, E. A. S. (1981) Rate of degradation and efficiency of conversion of phytoplarkton debris by marine microorganisms. Mar Ecol. Prog. Ser. 6 : $123-136$

Newell, R. C., Field, J. G., Griffiths, C. L. (1982). Energy balance and significance of microorganisms in a kelp bed community. Mar Ecol. Prog. Ser. 8: 103-113

Newell, R. C., Linley, E. A. S., Lucas, M. I. (1983). Bacterial production and carbon conversion based on saltmarsh plant debris. Estuar. coast. Shelf Sci. 17: 405-419

Newell, S. Y., Christian, R. R. (1981). Frequency of dividing cells as an estimator of bacterial productivity. Appl. environ. Microbiol. 42: 23-31

Novak, R. (1984). A study in ultra-ecology: microorganisms on the seagrass Posidonia oceanica (L.) Delile. P.S.Z.N.I. Mar Ecol. 5: 143-190

Novitsky, J., Morita, R. Y (1978). Possible strategy for the survival of marine bacteria under starvation conditions Mar. Biol. 48: 289-295

Ott, J. A. (1981). Adaptive strategies at the ecosystem level: examples from two benthic marine systems. P.S.Z.N.I Mar. Ecol. 2: 113-158

Ott, J., Maurer, L. (1977). Strategies on energy transfer from marine macrophytes to consumer levels: the Posidonia oceanica example. In: Keegan, B. F., Ceidigh, P. O., Boaden, P. S. (eds.) Biology of benthic organisms. Pergamon Press, Oxford, p. 493-502

Oudet, C., Gerard, R., Morin, P., Gningue, I. (1988). Precise 
shipboard determination of dissolved oxygen (Winkler procedure) for productivity studies with a commercial system. Limnol. Oceanogr. 33: 146-150

Parsons, T R., Maita, Y., Lalli, C. M. (1985). A manual of chemical and biological methods for seawater analysis. Pergamon Press, Oxford, p. 173

Phillips, R. C., MCRoy, C. P. (1980). Handbook of seagrass biology - an ecosystem perspective. Garland STPM Press, New York

Schultz, J. S., Gerhardt, P. (1969). Dialysis culture of microorganisms: design, theory and results. Bact. Rev. 33: 1-47

Sieburth, J. McN. (1976). Bacterial substrates and productivity in marine ecosystems. A. Rev. Ecol. Syst. 7: 259-285

Sieburth, J. McN. (1979). Sea microbes. Univ. Press, New York, p. 491

Sieburth, J. McN., Johnson, K. N., Burney, C. M., Lavoie, D. M. (1977). Estimation of in situ rates of heterotrophy using diurnal changes in organic matter and growth rates of picoplankton in diffusion culture. Helgoländer wiss. Meeresunters. 30: 565-574

Sieburth, J. McN., Smetacek, V., Lenz, J. (1978). Pelagic ecosystem structure: heterotrophic compartments of the plankton and their relationship to plankton size fractions. Limnol. Oceanogr 23: 1256-1263

Traer, K.(1980). The consumption of Posidonia oceanica (L.) Delile by echinoids at the isle of Ischia. In: Jangoux, M. (ed.) Echinoderms: present and past. Balkema, Rotterdam, p. $241-244$

Thayer, G. W., Adams, S. M., La Croix, M. W. (1975). Structural and functional aspects of a recently established Zostera marina community. In: Cronin, L. E. (ed.) Estuarine research, Vol. 1. Academic Press, New York, p. 518-546

Turley, C. M., Lochte, K. (1985). Direct measurement of bac-

This manuscript was presented by G. Rheinheimer, Kiel, Germany terial productivity in stratified waters close to a front in the Irish Sea. Mar Ecol. Prog. Ser. 23: 209-219

Turley, C., Lochte, K. (1986). Diel changes in specific growth rates and mean cell volume of natural bacterial communities in two different water masses in the Irish Sea. Microb. Ecol. 12: 271-282

Vargo, G. A., Hargravees, P. E., Johnson, P. (1975). Scanning electron microscopy of dialysis tubes incubated in flowing seawater. Mar Biol. 31. 113-120

Velimirov. B. (1986a). DOC dynamics in a Mediterranean seagrass system. Mar. Ecol. Prog Ser. 28: 21-41

Velimirov, B. (1986). Plant-herbivore relationships. Monografias Biologicas 4: 129-144

Velimirov, B. (1987). Organic matter derived from a seagrass meadow: Origin, properties and quality of particles. P.S.Z.N.I. Mar. Ecol. 8: 143-173

Velimirov, B. (1989). Il ruolo dei batteri nei flussi di energia un approccio ecosistemico. CEbalia 15: 25-46

Velimirov, B., Ott, J. A., Novak, R. (1981). Microorganisms on macrophyte debris: biodegradation and its implication in the food web. Kieler Meeresforsch., Sonderh. 5: 333-344

Vyshkvartsev, D. I. (1980). Bacterioplankton in shallow inlets of Posyela Bay. Microbiology 48: 603-609

Watson, S. W., Novitsky, T. J., Quinby, H. L., Valois, F. W. (1977). Determination of bacterial number and biomass in the marine environment. Appl. environ. Microbiol. 33: 940-954

Williams, P. J. LeB., Robertson, J. E. (1991). Overall planktonic oxygen and carbon dioxide metabolisms: The problem of reconciling observations and calculations of photosynthetic quotients. J. Plankton Res. 13: 153-169

Zimmermann, R., Gibson, R., Harrington, J. (1979). Herbivory and detritivory among gammaridean amphipods from a Florida seagrass community. Mar. Biol. 54: 41-47

Manuscript first received: August 30, 1991

Revised version accepted: January 8, 1992 